\title{
RELATIONSHIP OF THE RENAL CLEARANCES OF T-1824 AND OF ALBUMIN IN SOME PATIENTS WITH PROTEINURIA
}

\author{
By F. P. CHINARD, ${ }^{1}$ H. D. LAUSON, ${ }^{2}$ AND H. A. EDER ${ }^{3}$ \\ (From the Hospital of The Rockefeller Institute for Medical Research, New York, New York)
}

(Submitted for publication January 31, 1950; accepted August 1, 1952)

Studies of the mechanism of proteinuria and particularly of albuminuria require the application of accurate methods to the determination of the concentrations of individual proteins in plasma and urine. Electrophoresis is not practical because of the very large number of analyses necessary. The availability of human plasma albumin (i.e., fraction V) has permitted extensive use of immunological techniques (1-3). However, the small but significant amounts of globulins present in this fraction and the tedious procedure required in the preparation of antiserum warranted the investigation of possible alternative methods for the estimation of the renal clearance of albumin.

The blue dye T-1824, used clinically for the estimation of plasma volume, is bound in plasma principally to the albumin fraction (4); it does not appear in urine in significant amounts unless there is a significant proteinuria. On the basis of these two facts it has been suggested that the clearance of the dye might be a measure of the clearance of albumin. The first investigation of the clearance of the dye was carried out by Luetscher some years ago (5); the clearance of the dye was proportional to the clearance of the total protein and approximately four times as great. Since the albumin clearance was nearly four times the total protein clearance it is evident that there was good correlation between the dye and albumin clearances. Data were also given directly comparing the dye and albumin clearances in two instances: in the first the dye clearance was $0.37 \mathrm{ml} . / \mathrm{min}$., in the second the dye clearance was $0.75 \mathrm{ml} . / \mathrm{min}$. compared to the albumin clearance of $0.66 \mathrm{ml} . / \mathrm{min}$.

\footnotetext{
1 Present address : Departments of Medicine and Physiological Chemistry, The Johns Hopkins School of Medicine, Baltimore, Md.

2 Present address: Departments of Physiology and Pediatrics, Cornell University Medical College and the New York Hospital, New York, N. Y.

${ }^{3}$ Present address: Department of Medicine, Cornell University Medical College and the New York Hospital, New York, N. Y.
}

The albumin concentrations were determined electrophoretically. More recently, Allen and Orahovats (6) have investigated the clearance of $\mathrm{T}-1824$ in normal dogs. From a comparison of their data for T-1824 in dogs with the data on protein excretion in normal human subjects obtained by Gunton and Burton (7) they suggested that the renal clearances of albumin and of T-1824 might be identical.

The present report describes the results of direct comparisons of the renal clearances of the dye and of albumin in patients with the nephrotic syndrome. Results are also given of direct comparisons in some of these patients after changes in the plasma albumin concentration had been obtained by the infusion of concentrated human plasma albumin. ${ }^{4}$

\section{METHODS}

a. Concentration of T-1824 in plasma. A previously described acetone extraction method was used to determine the concentration of $T-1824$ in plasma $(8,9)$. The increment of optical density $(\Delta D)$ for a given increment of plasma dye concentration $(\Delta C)$ is a function of protein concentration but follows the Bouguer-Beer Law for any given protein concentration. In some of the experiments reported below, the plasma protein concentration changed significantly from one period to the next following the administration of human plasma albumin or, in one experiment, the administration of blood. In these experiments it was necessary to determine $\Delta D / \Delta C$ for each sample of plasma. This was done as follows: From each plasma sample containing dye two $1 \mathrm{ml}$. aliquots were taken. To one, A, was added a known amount of dye in $0.2 \mathrm{ml}$. of 0.85 per cent $\mathrm{NaCl}$. To the other, $\mathrm{B}$, was added $0.2 \mathrm{ml}$. of 0.85 per cent $\mathrm{NaCl}$. From this point on, the acetone extraction procedure was followed. The optical densities of the acetone extracts of $A\left(D_{\Delta}\right)$ and of

4 The albumin used in these studies was prepared from the blood of voluntary donors by the American National Red Cross. This material has been supplied to investigators by the American Red Cross as part of its $\mathrm{Na}$ tional Blood Program. The opinions and conclusions are those of the authors and do not necessarily reflect the policy of the National Blood Program. 
TABLE I

Comparison of clearances of albumin and T-1824 in J.R., male, aged 5 years

\begin{tabular}{|c|c|c|c|c|c|c|c|}
\hline \multirow{2}{*}{ Date } & \multirow{2}{*}{ Time of urine collection } & \multirow{2}{*}{ Urine flow } & \multicolumn{2}{|c|}{ Plasma concentration } & \multicolumn{3}{|c|}{ Renal plasma clearance } \\
\hline & & & Albumin & $\mathrm{T}-1824$ & Albumin & $\mathrm{T}-1824$ & $\frac{C_{T-1824}}{C_{\text {alb }}}$ \\
\hline $\begin{array}{c}\text { Dec. 2, } 1948 \\
\text { (Control) }\end{array}$ & $\begin{aligned} & 10: 26 \text { a.m. }-12: 09 \text { p.m. } \\
&-12: 43 \\
&-1: 00 \\
&-2: 10 \\
&-3: 30 \\
&-4: 06 \\
&-5: 43 \\
&-7: 08 \text { p.m. }\end{aligned}$ & $\begin{array}{c}\text { ml. } / \text { min. } \\
0.25 \\
0.47 \\
0.59 \\
0.40 \\
0.60 \\
0.78 \\
0.58 \\
0.51\end{array}$ & $\begin{array}{c}\mathrm{gm} . / 100 \mathrm{ml} . \\
0.38 \\
0.38 \\
0.38 \\
0.385 \\
0.39 \\
0.39 \\
0.39 \\
0.39\end{array}$ & $\begin{array}{c}\mu g m . / \mathrm{ml} . \\
16.8 \\
14.2 \\
13.4 \\
12.2 \\
10.2 \\
8.65 \\
7.55 \\
6.60\end{array}$ & $\begin{array}{c}\text { ml./min. } \\
0.68 \\
0.99 \\
1.25 \\
0.81 \\
0.81 \\
0.93 \\
1.00 \\
0.81\end{array}$ & $\begin{array}{c}\text { ml. } / \text { min. } \\
0.43 \\
0.70 \\
0.94 \\
0.56 \\
0.61 \\
0.80 \\
0.70 \\
0.63\end{array}$ & $\begin{array}{l}0.63 \\
0.71 \\
0.69 \\
0.70 \\
0.75 \\
0.86 \\
0.70 \\
0.77\end{array}$ \\
\hline Dec. 14,1948 & 9:00 a.m.- 9:45 a.m. & \multicolumn{6}{|c|}{$25 \mathrm{gm}$. albumin intravenously } \\
\hline $\begin{array}{l}\text { (after } 25 \mathrm{gm} . \\
\text { albumin) }\end{array}$ & $\begin{aligned} 10: 02 \text { a.m. } & -10: 31 \text { a.m. } \\
& -11: 48 \\
& -12: 25 \text { p.m. } \\
& -1: 17 \\
& -1: 56 \\
& -2: 55 \\
& -3: 20 \\
& -3: 40 \\
& -4: 58 \\
& -5: 53 \\
& -6: 53 \\
& -8: 17 \text { p.m. }\end{aligned}$ & $\begin{array}{l}2.48 \\
2.29 \\
2.00 \\
2.54 \\
2.80 \\
1.80 \\
2.56 \\
1.60 \\
0.90 \\
0.62 \\
0.48 \\
0.33\end{array}$ & $\begin{array}{l}1.72 \\
1.67 \\
1.45 \\
1.37 \\
1.31 \\
1.24 \\
1.18 \\
1.17 \\
1.12 \\
1.02 \\
0.92 \\
0.81\end{array}$ & $\begin{array}{l}15.6 \\
13.5 \\
11.8 \\
11.0 \\
10.2 \\
9.30 \\
8.60 \\
8.35 \\
7.65 \\
6.65 \\
5.75 \\
4.85\end{array}$ & $\begin{array}{l}2.37 \\
1.90 \\
2.19 \\
2.11 \\
1.96 \\
2.07 \\
2.18 \\
2.28 \\
1.85 \\
2.05 \\
1.63 \\
1.49\end{array}$ & $\begin{array}{l}1.99 \\
1.83 \\
1.93 \\
1.85 \\
1.76 \\
1.91 \\
2.02 \\
1.94 \\
1.79 \\
1.82 \\
1.42 \\
1.31\end{array}$ & $\begin{array}{l}0.84 \\
0.96 \\
0.88 \\
0.88 \\
0.90 \\
0.92 \\
0.93 \\
0.85 \\
0.97 \\
0.89 \\
0.87 \\
0.88\end{array}$ \\
\hline
\end{tabular}

$B\left(D_{B}\right)$ were read in the Coleman Model $6 \mathrm{~A}$ clinical spectrophotometer in $12 \times 75 \mathrm{~mm}$. cuvettes at $\lambda=620 \mathrm{~m} \mu$ with the instrument set at zero with distilled water. $\Delta \mathrm{D}=\mathrm{D}_{\Delta}-\mathrm{D}_{\mathrm{B}}$. This value of $\Delta \mathrm{D}$ was then plotted against the amount in $\mu \mathrm{gm}$ of dye added to $1 \mathrm{ml}$. of plasma A. A straight line was drawn through the point and the origin, and the concentration of dye equivalent to $D_{B}$ was read from this line. In a large series of determinations on the control plasma of nephrotic patients the difference between distilled water and an acetone extract of plasma free of dye was found to range from 0.000 to 0.003 optical density units. Therefore no significant error was introduced by the assumption that the optical density of an acetone extract of plasma was due solely to dye. This is of importance because residual dye from previous injections was present in the plasma of several patients at the beginning of the experimental period. 5

5 When plasma volumes were estimated during the course of an experiment the procedure previously described (7) was used for the determination of the relative dye concentrations. To obtain the absolute dye concentrations required for the calculation of clearances the reference solution used was standardized by comparison with a solution containing a known concentration of dye. Between 1 and $5 \mathrm{ml}$. of 0.5 per cent T-1824 was injected per liter of plasma volume; the resultant maximum dye to albumin molar concentration ratio was approximately $1: 8$. Urine collections for the clearance studies were started no sooner than 20 minutes after the injection of the dye.
In general, duplicate analyses of the plasma concentrations of dye could not be made because of the limited amount of blood that could be safely removed from each patient. However, about 10 per cent of the determinations were repeated because of apparent discrepancies with other analyses; these duplicates showed no more than 2 per cent variation.

b. Concentration of T-1824 in urine. Urine samples, if cloudy, were cleared by centrifugation; extraction with acetone was not necessary. To accurately measured aliquots of urine containing dye, there were added $1.0 \mathrm{ml}$. of molar phosphate buffer of $\mathrm{pH} 7.0$ and enough 0.85 per cent $\mathrm{NaCl}$ to make the final volume $5.0 \mathrm{ml}$. The volume of urine was chosen so that the final optical densities were above 0.10 in $12 \times 75 \mathrm{~mm}$. cuvettes at $\lambda=620 \mathrm{~m} \mu$ with the instrument set at zero with water. Standard curves were prepared by adding a known amount of dye to a buffered control urine; thus $\Delta \mathrm{D} / \Delta \mathrm{C}$ was found for the urine for each experiment. Blanks were troublesome because it was not possible to determine accurately what fraction of the blank was contributed by the naturally occurring urine pigments and what fraction was contributed by dye still being excreted as the result of previous injections of dye. Ideally, the blank contributed by the urine pigments should have been calculated on the basis of excretion per minute; this was not possible and no blank correction was made. Because of the relatively high dye clearances in these patients, the effect of this omission on the calculated dye clearances is to make them too high by at most 5 per cent. Where lower clearances 
TABLE II

Comparison of clearances of albumin and T-1824 in A. McE., female, aged $5 \frac{1}{2}$ years

\begin{tabular}{|c|c|c|c|c|c|c|c|}
\hline \multirow[b]{2}{*}{ Date } & \multirow[b]{2}{*}{ Time of urine collection } & \multirow[b]{2}{*}{ Urine flow } & \multicolumn{2}{|c|}{ Plasma concentration } & \multicolumn{3}{|c|}{ Renal plasma clearance } \\
\hline & & & Albumin & $\mathrm{T}-1824$ & Albumin & $T-1824$ & $\frac{C_{T-1824}}{C_{\text {alb }}}$ \\
\hline Dec. 3, 1948 & 9:40 a.m.-10:45 a.m. & ml./min. & $\begin{array}{r}\mathrm{gm} . / 100 \mathrm{ml} \\
37 .\end{array}$ & $\begin{array}{l}\mu g m . / m l . \\
\text { m. albu }\end{array}$ & $\begin{array}{l}\text { ml./min. } \\
\text { intraver }\end{array}$ & $\begin{array}{l}\text { ml./min. } \\
l y\end{array}$ & \\
\hline $\begin{array}{l}\text { (after } 37.5 \mathrm{gm} . \\
\text { albumin) }\end{array}$ & $\begin{aligned} \text { 1:37 p.m. } & 2: 19 \text { p.m. } \\
& =3: 04 \\
& -3: 37 \\
& -3: 50 \\
& -4: 34 \text { p.m. }\end{aligned}$ & $\begin{array}{l}1.31 \\
1.02 \\
0.75 \\
1.15 \\
1.05\end{array}$ & $\begin{array}{l}2.79 \\
2.69 \\
2.63 \\
2.62 \\
2.60\end{array}$ & $\begin{array}{l}17.6 \\
16.4 \\
15.5 \\
15.2 \\
14.7\end{array}$ & $\begin{array}{l}1.94 \\
1.55 \\
0.64 \\
1.00 \\
1.18\end{array}$ & $\begin{array}{l}1.37 \\
1.21 \\
0.50 \\
0.78 \\
1.02\end{array}$ & $\begin{array}{l}0.71 \\
0.78 \\
0.79 \\
0.78 \\
0.86\end{array}$ \\
\hline Dec. 4, 1948 & $\begin{aligned} & \text { 9:41 a.m. }-11: 08 \text { a.m. } \\
&-12: 12 \text { p.m. } \\
&-12: 48 \\
&-1: 29 \\
&-2: 01 \\
&-3: 24 \\
&-4: 03 \\
&-4: 45 \\
&-6: 01 \\
&-7: 03 \\
&-8: 38 \\
&-10: 10 \\
&-11: 47 \text { p.m. } \\
&-2: 55 \text { a.m. } \\
&-5: 59 \\
&-9: 56 \text { a.m. }\end{aligned}$ & $\begin{array}{l}0.67 \\
0.73 \\
0.50 \\
0.98 \\
1.72 \\
0.95 \\
1.51 \\
0.95 \\
0.40 \\
0.53 \\
0.38 \\
0.37 \\
0.36 \\
0.27 \\
0.27 \\
0.28\end{array}$ & $\begin{array}{l}1.80 \\
1.67 \\
1.60 \\
1.55 \\
1.55 \\
1.54 \\
1.53 \\
1.53 \\
1.53 \\
1.52 \\
1.52 \\
1.51 \\
1.50 \\
1.50 \\
1.48 \\
1.47\end{array}$ & $\begin{array}{l}25.2 \\
23.0 \\
21.9 \\
20.9 \\
20.3 \\
19.5 \\
18.7 \\
18.2 \\
17.3 \\
16.3 \\
15.3 \\
14.3 \\
13.5 \\
12.4 \\
11.2 \\
9.95\end{array}$ & $\begin{array}{l}0.67 \\
0.75 \\
0.82 \\
0.81 \\
1.08 \\
0.72 \\
0.80 \\
0.80 \\
0.76 \\
0.82 \\
0.54 \\
0.54 \\
0.52 \\
0.41 \\
0.40 \\
0.42\end{array}$ & $\begin{array}{l}0.50 \\
0.54 \\
0.58 \\
0.57 \\
0.76 \\
0.54 \\
0.58 \\
0.57 \\
0.51 \\
0.57 \\
0.42 \\
0.40 \\
0.38 \\
0.32 \\
0.33 \\
0.39\end{array}$ & $\begin{array}{l}0.75 \\
0.72 \\
0.70 \\
0.70 \\
0.71 \\
0.75 \\
0.73 \\
0.71 \\
0.67 \\
0.70 \\
0.77 \\
0.75 \\
0.74 \\
0.78 \\
0.82 \\
0.92\end{array}$ \\
\hline
\end{tabular}

of dye than those reported here are found, a pigment blank correction becomes essential.

Another possible source of error is the change in the absorption coefficient for the dye with changes in the protein to dye molar concentration ratios. Fortunately, under the conditions of the experiments reported here the albumin to dye molar concentration ratios were between 1 and 100 , in a range where there is very little change in the dye absorption coefficient (10). Since the Coleman Model 6A clinical spectrophotometer isolates a band approximately $35 \mathrm{~m} \mu$ wide, changes in absorption coefficient at a given wavelength setting and shifts of absorption maxima are much less evident with this instrument than with the Beckman quartz spectrophotometer.

Replicate determinations of dye concentrations in urine, on some occasions two or three days apart, showed in the absence of marked bacterial growth no greater variation than \pm 1.5 per cent.

c. Albumin concentrations in plasma and urine. Albumin concentrations were estimated by an immunological procedure similar to that described by Kunkel and Ward (11). Since T-1824 is bound to albumin in plasma and presumably in urine, the possibility that $\mathrm{T}-1824 \mathrm{might}$ interfere with the antigen-antibody reaction was examined. T-1824 was added to an albumin solution in 0.85 per cent $\mathrm{NaCl}$ in a molar concentration ratio of dye to albumin of 14 to 1 ; antiserum was added to this solution and to a solution of albumin of the same concentration but without T-1824. The presence of T-1824 made no detectable difference in the amount of precipitate formed; no dye was found in the antigen-antibody precipitate. The possibility of interference by $\mathrm{NH}_{4}^{+}$was eliminated by the fact that addition of $\mathrm{NH}_{4} \mathrm{Cl}$ to albumin prior to reaction with the antiserum did not result in any greater optical density after reaction with ninhydrin than when $\mathrm{NH}_{4} \mathrm{Cl}$ was not added.

d. Patients. See $(3,12)$.

e. Urine collections. All specimens of urine were spontaneously voided.

\section{RESULTS}

In Table I are given comparisons of the dye and albumin clearances in patient J. R. on a control day and after the intravenous administration of albumin on another day. Table II presents similar data obtained from an experiment on patient $A$. $\mathrm{McE}$.: in this experiment clearances were estimated over a period of approximately 48 hours after the administration of $37.5 \mathrm{gm}$. of human serum albumin. Figure 1 summarizes the data on comparisons between dye and albumin clearances. It will be noted that the two clearances are not in an exact 1 to 1 ratio and that nearly all the T-1824 clearances are smaller than the corresponding albumin clearances. The means, standard devia- 


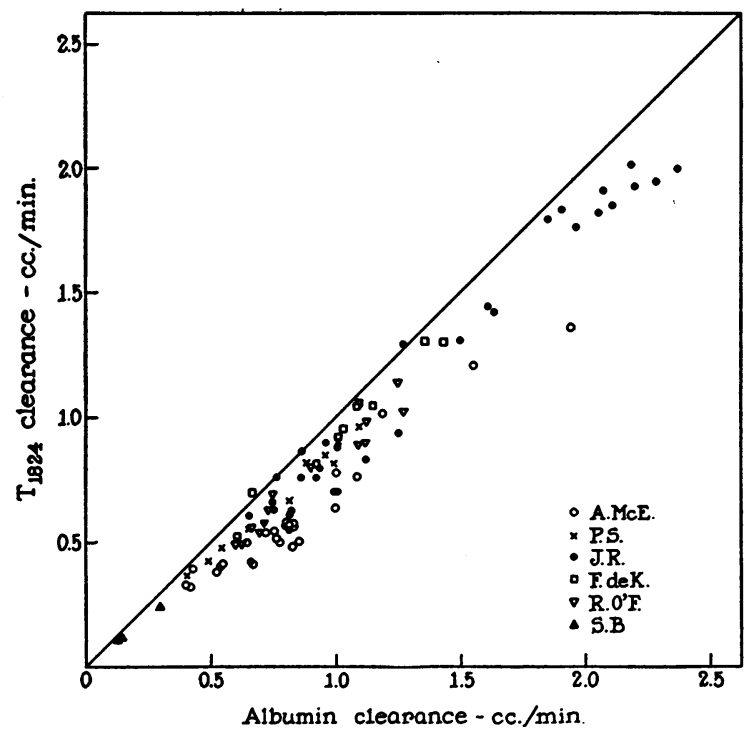

Fig. 1. Relationship of the T-1824 and Albumin Clearances

The straight line is the locus of a ratio of 1.0.

tions, and coefficients of variation of the clearance ratios are given in Table III for each experiment on each patient and for all the data taken together. The extent of variability found is not surprising since the ratios include the errors of four analyses: urine and plasma T-1824 concentrations and urine and plasma albumin concentrations. For a given experiment in a given patient the standard deviation of the clearance ratios is less than the stand- ard deviation of all the clearance ratios taken together.

\section{DISCUSSION}

It is evident from the data that there is a reasonably good agreement between the clearance of the dye T-1824 and the clearance of albumin when the albumin concentrations are estimated by the immunological procedure used here. This result was expected because $\mathrm{T}-1824$ is preferentially bound to albumin in plasma and presumably also in urine. The fact that the clearances are not identical warrants brief comment.

The most obvious explanation of the discrepancy in the clearances is that there is a systematic error in the albumin clearances : the albumin clearances may be too high. This could occur either if the values for the plasma concentration of albumin were too low or if the values for the urine concentration of albumin were too high; the alternatives are not mutually exclusive. The probability that this explanation is correct is lessened by the following facts. The antigen used to prepare the anti-serum contains approximately 2 per cent alpha-globulins. As pointed out elsewhere (3) the renal clearance of alpha-globulins is much smaller than the clearance of albumin. If the immunological method determines some alpha-globulin as albumin the clearance values for albumin would be too low rather than too high.

TABLE III

Summary of the comparisons of the renal plasma clearances of T-1824 and albumin

\begin{tabular}{|c|c|c|c|c|c|c|c|}
\hline \multirow{2}{*}{\multicolumn{2}{|c|}{ Patient }} & \multirow{2}{*}{ Date } & \multirow{2}{*}{$\begin{array}{c}\text { Number } \\
\text { of } \\
\text { periods }\end{array}$} & \multirow{2}{*}{$\begin{array}{l}\text { Range of } \\
\text { albumin } \\
\text { clearances }\end{array}$} & \multicolumn{3}{|c|}{$\frac{T-1824 \text { clearance }}{\text { Albumin clearance }}$} \\
\hline & & & & & Mean & $\begin{array}{l}\text { Standard } \\
\text { deviation }\end{array}$ & $\begin{array}{l}\text { Coefficient } \\
\text { of variation }\end{array}$ \\
\hline A. McE. & (after albumin) & $\begin{array}{l}\text { Dec. } 3-5,1948 \\
\text { Dec. } 21-22,1948\end{array}$ & 21 & $\begin{array}{l}\text { ml./min. } \\
0.40-1.94 \\
0.67-0.99\end{array}$ & $\begin{array}{l}0.75 \\
0.64\end{array}$ & $\begin{array}{l} \pm 0.057 \\
\pm 0.066\end{array}$ & $\begin{array}{l}\text { per cent } \\
\pm 7.6 \\
\pm 10.3\end{array}$ \\
\hline J. R. & $\begin{array}{l}\text { (control) } \\
\text { (after albumin) } \\
\text { (before and after blood) }\end{array}$ & $\begin{array}{l}\text { Dec. } 1-2,1948 \\
\text { Dec. } 14-15,1948 \\
\text { Feb. } 2-3,1949\end{array}$ & $\begin{array}{r}8 \\
12 \\
12\end{array}$ & $\begin{array}{l}0.68-1.25 \\
1.49-2.37 \\
0.65-1.61\end{array}$ & $\begin{array}{l}0.73 \\
0.90 \\
0.91\end{array}$ & $\begin{array}{l} \pm 0.066 \\
\pm 0.041 \\
\pm 0.081\end{array}$ & $\begin{array}{l} \pm 9.0 \\
\pm 4.6 \\
\pm 8.9\end{array}$ \\
\hline P. S. & (after albumin) & Dec. $14-15,1948$ & 10 & $0.40-1.09$ & 0.88 & \pm 0.039 & \pm 4.4 \\
\hline R. O'F. & (after albumin) & Dec. 1-2, 1948 & 13 & $0.60-1.27$ & 0.84 & \pm 0.055 & \pm 6.5 \\
\hline F. deK. & (after albumin) & Dec. $13-14,1948$ & 10 & $0.61-1.42$ & 0.94 & \pm 0.059 & \pm 6.9 \\
\hline S. B. & & Dec. 8, 1948 & 3 & $0.13-0.30$ & 0.85 & 一 & 一 \\
\hline All cases & & & 94 & $0.13-2.37$ & 0.83 & \pm 0.101 & \pm 12.2 \\
\hline
\end{tabular}


It is possible that the discrepancies are related to the existence of two or more plasma albumins. Luetscher found that albumin was homogeneous on electrophoresis at $\mathrm{pH}>7$; at $\mathrm{pH} 4.0$ there were two distinct components (13). Cohn, Hughes and Weare working with crystallized serum albumin reported that they had confirmed Luetscher's findings (14). Hughes has identified a distinct fraction, mercaptalbumin, in crystalline albumin (15). If native albumin or albumin which has been carried through the ethanol fractionation procedure is a mixture of two (or more) proteins there is no assurance that these proteins have identical clearances. Nor is there any assurance that $\mathrm{T}-1824$ is bound in exactly the same manner to the two proteins.

With respect to $\mathrm{T}-1824$, it is unlikely (though not impossible) that a large fraction of the dye is bound to other proteins such as the alpha-globulins at the in vivo dye to protein concentration ratios of our experiments. Rawson (4) has demonstrated that T-1824 added to whole plasma migrates with albumin during electrophoresis at $\mathrm{pH}$ 7.4 when the molar ratio of $\mathrm{T}-1824$ to albumin is less than 14 to 1 . Another possibility is that some of the T-1824 may be reabsorbed by the tubular cells independently of the "reabsorption" of albumin. Finally, some of the dye may be destroyed (e.g., by reduction of the azo groups) on passage down the tubules.

Regardless of which, if any, of the above possibilities is correct, the data indicate the extent to which the clearance of $\mathrm{T}-1824$ may be depended on as a measure of the clearance of albumin.

\section{SUM MARY}

The renal plasma clearances of the blue dye T-1824 and of human plasma albumin have been estimated simultaneously in patients with the nephrotic syndrome. In 94 periods in 6 patients the ratio, T-1824 clearance/albumin clearance, averaged 0.83 (standard deviation, \pm 0.101 ). Concentrations of albumin in plasma and urine were estimated by means of an immunological procedure. The T-1824 clearance should be useful as a substitute for the albumin clearance where direct methods for the albumin clearance are not available or where it is desirable to estimate a large number of clearances. The T-1824 clearance is proportional to, though not identical with, the albumin clearance over a wide range of albumin clearance values. Possible explanations of the discrepancy between the clearances are discussed.

\section{ACKNOWLEDGMENT}

It is a pleasure to acknowledge the technical assistance of Miss Dora M. Newell.

\section{REFERENCES}

1. Lauson, H. D., Chinard, F. P., and Eder, H. A., Renal mechanism of albumin excretion in patients with nephrotic syndrome. Federation Proc., 1949, 8, 91.

2. Smith, H. W., The Kidney. Structure and Function in Health and Disease. Oxford University Press, New York, 1951, page $861 \mathrm{ff}$.

3. Chinard, F. P., Lauson, H. D., Eder, H. A., Greif, R. L., and Hiller, A., Studies of the nephrotic syndrome. II. Renal excretion and clearance of albumin in relation to the concentration of albu$\min$ in plasma and to the renal clearance of endogenous "creatinine." In preparation.

4. Rawson, R. A., The binding of T-1824 and structurally related diazo dyes by the plasma proteins. Am. J. Physiol., 1942-43, 138, 708.

5. Luetscher, J. A., Jr., The effect of a single injection of concentrated human serum albumin on circulating proteins and proteinuria in nephrosis. J. Clin. Invest., 1944, 23, 365.

6. Allen, T. H., and Orahovats, P. D., Spectrophotometric measurement of traces of the dye T-1824 by extraction with cellophane from both blood serum and urine of normal dogs. Am. J. Physiol., 1948, 154, 27.

7. Gunton, R., and Burton, A. C., On the concentration of protein in samples of normal urine measured by its surface activity. J. Clin. Invest., 1947, 26, 892.

8. Chinard, F. P., and Eder, H. A., The determination of the concentration of the dye T-1824 in normal and lipemic plasma. J. Exper. Med., 1948, 87, 473.

9. Chinard, F. P., Estimation of plasma volume by dye dilution method, in Methods in Medical Research, edited by M. B. Visscher. The Yearbook Publishers, Inc., Chicago, 1951, Vol. IV, p. 38.

10. Chinard, F. P., unpublished data.

11. Kunkel, H. G., and Ward, S. M., The immunological determination of human albumin in biological fluids. J. Biol. Chem., 1950, 182, 597.

12. Lauson, H. D., Eder, H. A., Chinard, F. P., Greif, R. L., Hiller, A., Cotzias, G. C., and Van Slyke, D. 
D., Studies of the nephrotic syndrome. I. Certain physiological and clinical effects of intravenous administration of human plasma albumin. In preparation.

13. Luetscher, J. A., Jr., Serum albumin. II. Identification of more than one albumin in horse and human serum by electrophoretic mobility in acid solution. J. Am. Chem. Soc., 1939, 61, 2888.
14. Cohn, E. J., Hughes, W. L., Jr., and Weare, J. H., Preparation and properties of serum and plasma proteins. XIII. Crystallization of serum albumins from ethanol-water mixtures. J. Am. Chem. Soc., 1947, 69, 1753.

15. Hughes, W. L., Jr., An albumin fraction isolated from human plasma as a crystalline mercuric salt. J. Am. Chem. Soc., 1947, 69, 1836. 